http:/ /e-journal.stit-islamic-village.ac.id/index.php/JECIES

\title{
PENINGKATAN KECERDASAN BODY KINESTHETIC MELALUI KEGIATAN TARI KREATIF (Penelitian Tindakan di Kelompok B TK/RA Daaruttuqo, Cipondoh)
}

\author{
Rosita \\ STIT Islamic Village Tangerang \\ Email: Rositaikt1981@gmail.com
}

Received: 20 Juli, 2020.

Accepted: 12 Agustus, 2020.

Published: 30 September, 2020

\begin{abstract}
Objectives of the research are to determine the creative dance and to increase body kinesthetic intelligence of children through creative dance. This research was carried out in group B Daaruttuqo kindergarten, Cipondoh Tangerang with 10 subject, on the month from May to June. This research uses an action research design model of Kemmis and Mc Taggart, through two cycles consisting of seven meetings on the first cycle and seven meetings on the second cycle which includes the stages of planning, action, observation and reflection. Data analysis using quantitative and qualitative analysis. Data obtained by referring to the research instrument which refers to the body kinesthetic intelligence. The results showed an increase in body kinesthetic intelligence scores of children with the acquisition of body kinesthetic intelligence classical pre-action reached $37.5 \%$, the first cycle increased the score reached $56.75 \%$ and the second cycle was obtained which satisfy the classical score reached $80.75 \%$ so it can be concluded that the activity"creative dance" can improve children's body kinesthetic intelligence.
\end{abstract}

\begin{abstract}
ABSTRAK
Penelitian ini dilakukan dengan latar belakang kurangnya penghargaan orang tua tentang kecerdasan jamak anak-anaknya, sehingga hanya menstimulasi beberapa kecerdasan yang dimiliki anak seperti kecerdasan matematika dan bahasa (calistung). Selain itu kurangnya stimulasi yang tepat terbadap kecerdasan body kinesthetik anak-anak usia dini yang ada di sekolah tersebut. Dengan demikian tujuan penelitian ini adalah untuk mengetabui proses meningkatkan kecerdasan body kinesthetic anak melalui kegiatan tari kreatif. Penelitian ini dilaksanakan di kelompok B TK/RA Daaruttuqo Cipondoh Tangerang. Dengan waktu pelaksanaan di bulan Mei sampai Juni. Penelitian ini menggunakan rancangan penelitian tindakan dengan model Kemmis dan Mc Taggart, melalui dua siklus yang tediri dari tujuh pertemuan pada siklus I dan tujub pertemuan pada siklus II yang meliputi tahap perencanaan, tindakan, observasi dan refleksi. Analisis data menggunakan analisis kuantitatif dan kualitatif. Data diperoleh dengan berpedoman pada instrumen penelitian yang mengacu pada aspek. kecerdasan body kinesthetic. Hasil penelitian menunjukkan adanya peningkatan kecerdasan body kinesthetic anak dengan perolehan skor
\end{abstract}


kecerdasan body kinesthetic pra-tindakan mencapai $37.5 \%$, siklus I mengalami peningkatan skor mencapai $56.75 \%$ dan pada siklus II diperoleh skor yang memuaskan mencapai $80.75 \%$ sehingga dapat disimpulkan bahwa kegiatan tari kreatif dapat meningkatkan kecerdasan body kinesthetic anak. Dengan demikian penelitian ini diharapkan. memberikan stimulasi gerakan yang positif dan memiliki tujuan seperti kegiatan "tari kreatif”. Sehingga kegiatan tari kreatif ini menjadi alternatif dalam pemelajaran, contohnya proses yang terjadi di alam sekitar dengan refleksi gerakan, dengan cara yang ak.tif dan interaktif bagi anak.

Katakunci: kecerdasan body kinesthetic, tari kreatif, penelitian tindakan

\section{PENDAHULUAN}

Bergerak merupakan salah satu kebutuhan bagi Anak Usia Dini (AUD) setelah makan dan minum. Karena bergerak merupakan proses aktualisasi bagi setiap anak. Selain itu kebutuhan bergerak bagi Anak Usia Dini (AUD) juga merupakan tolak ukur dari kecerdasan dan daya tangkap seorang anak yang mengindikasikan bahwa seorang anak itu sehat dan berkembang sesuai perkembangannya. Bergerak merupakan koordinasi yang melibatkan semua panca indera dan anggota tubuh seorang anak yang akan menghasilkan suatu gerakan motorik. Karena motorik adalah: "Segala faktor yang bisa menimbulkan gerakan-gerakan pada seluruh bagian tubuh" (Kartini, 1995). Dengan kata lain "Segala sesuatu yang ada hubungannya dengan gerakan-gerakan tubuh merupakan motorik (Zulkifli, 2001)

Secara umum perkembangan motorik dapat dibedakan menjadi dua, yaitu motorik kasar dan motorik halus. Keterampilan motorik halus anak usia prasekolah biasanya dikembangkan dengan menggunakan alat permainan di dalam ruangan. Sedangkan perkembangan motorik kasar anak usia prasekolah biasanya dikembangkan dengan alat permainan besar yang berada di luar ruangan.

Namun dalam perkembangannya kegiatan motorik kasar berkembang lebih dulu dibanding motorik halus. Ini dibuktikan dengan kenyataan bahwa anak sudah dapat menggunakan otot-otot kakinya untuk berjalan sebelum ia mampu mengontrol tangan dan jari-jarinya untuk menggambar atau menggunting. Pada usia 3 tahun, sesuai dengan perkembangannya, anak umumnya sudah menguasai sebagian besar keterampilan motorik kasar.

Keterampilan motorik ini pada dasarnya berkembang sejalan dengan kematangan syaraf dan otot. Sehingga setiap gerakan yang dilakukan oleh seorang anak, sesederhana apapun, sebenarnya merupakan hasil pola interaksi yang kompleks dari berbagai bagian dan sistem dalam tubuh yang dikontrol oleh otak. Karena setiap anak mempunyai pola perkembangan kepribadian tertentu yang dipengaruhi oleh keadaan jasmani, mental intelektual, dan emosi. Keadaan fisik mempengaruhi tingkah laku dan penyesuaian diri terhadap lingkungan sekitar. Selain itu, perkembangan motorik juga 
dipengaruhi oleh unsur-unsur yang menentukan yaitu otot, syaraf, dan otak (Novita Sari, Eka Fitri dan Abdurrahman, Mulyono, dan Asnawi, 2012)

Masa lima tahun pertama adalah masa emas bagi perkembangan motorik anak. Hal itu disebabkan pada usia ini badan anak masih begitu lentur dan mudah diarahkan, ditambah dengan kesenangannya bereksplorasi dan seperti tak mengenal rasa takut, maka segala gerakan yang diajarkan pada anak akan dianggapnya sebagai suatu permainan yang menyenangkan.

Berbagai manfaat bisa diperoleh anak ketika ia semakin terampil menguasai gerakan motoriknya. Selain kondisi badan juga semakin sehat karena anak banyak bergerak, ia juga jadi lebih mandiri dan percaya diri. Anak semakin yakin dalam mengerjakan segala sesuatu karena sadar akan kemampuan fisiknya. Anak-anak yang baik perkembangan motoriknya, biasanya juga mempunyai keterampilan sosial positif. Mereka akan senang bermain bersama teman-temannya karena dapat mengimbangi gerak teman sebaya, seperti berlompat-lompatan dan berkejar-kejaran.

Hal inilah yang menjadikan seorang anak di kemudian hari menjadi anak yang memiliki kecerdasan bodi kinestetik.

Kecerdasan bodi kinestetik dicetuskan oleh Howard Gardner. Ia mengumumkan teori tujuh kecerdasan pada tahun 1983, belakangan menambahkan tiga kecerdasan yang lain sehingga menjadi sepuluh kecerdasan yang dibutuhkan manusia agar hidupnya sukses. Tujuh kecerdasan yang mula-mula diidentifikasikannya adalah: Kinestetik, verbal-linguistik, music, logik-matematik, spasial, interpersonal dan intrapersonal.Tiga kecerdasan yang belakangan dimasukannya adalah Naturalistik, Eksistensional dan spiritual (Massardi Yudhistira And, 2012) .

Salah satu kecerdasan yang menjadi perhatian Gardner adalah Kecerdasan bodi kinestetik. Secara sepintas, kemampuan ini sepertinya tidak mengesankan. Umumnya, kecerdasan gerak tubuh tidak diapresiasi dalam kultur hampir semua masyarakat. Bahkan, menyebutnya sebagai sebuah "kecerdasan" hampir mengemparkan. Kegemparan itu menyurut setelah Gardner menyebut Marcel Marceau, atlet, aktor, teater pantomim, penemu, dan penari, menjadi penguat teorinya tentang kecerdasan tubuh. Beliau menguraikan bahwa kemantapan diri yang dimiliki penari adalah bentuk kemampuan yang dimiliki setiap orang dalam "memahami secara langsung tindakan perasaan, atau kemampuan dinamis orang lain, tanpa bantuan kata maupun gambar (Massardi Yudhistira And, 2012).

Berbekal beberapa ungkapan dan teori para pakar yang tersebut, penulis mencoba menelaah kembali arti sebuah kecerdasan bodi kinestetik sebagai potret yang ideal dan mampu mencerdaskan anak bangsa dalam kemasan atau casing yang berbeda. Karena kecerdasan tidak dapat berdiri sendiri tapi harus dibantu dan saling melengkapi, seperti seorang yang cerdas raga, juga harus cerdas matematika supaya dia bisa mengestimasi gerakan 
sesuai dengan timing yang diperhitungkan, juga cerdas visual agar dapat menerka ruang dan medan geraknya. Selain itu kecerdasan bodi-kinestetik mampu mengasah motorik kasar yang membantu kematangan motorik halus hingga mampu menulis serta mengasah kemampuan sosial emosional anak usia dini sehingga lebih berani untuk tampil di depan publik.

Selain itu untuk memperkenalkan pada sebagian besar masyarakat yang masih awam mengenai makna motorik yang menjadi bagian dari kecerdasan bodi kinestetik sebagai kemampuan untuk menggunakan seluruh tubuhnya untuk mengekspresikan ide-ide dan perasaan-perasaan untuk menghasilkan dan mentransformasikan sesuatu. Kecerdasan ini mencakup keahlian-keahlian fisik khusus seperti: koordinasi, keseimbangan, ketangkasan, kekuatan, kelenturan dan kecepatan. (Amstrong, 2009)

Sehingga tidak terulang kembali survey tahun 2006 yang menunjukkan bahwa anak-anak Indonesia kurang memanfaatkan waktunya untuk melakukan aktifitas fisik karena mereka menghabiskan sebagian besar waktu mereka untuk belajar dan kegiatan non fisik seperti nonton TV dan bermain game(Rendabnya Physical Quotient Anak-anak di Indonesia, 2013) . Dan kegiatan yang menggunakan tekhnologi ( seperti HP dsb.) sebaiknya dibatasi, terlebih usia 0-2 tahun sepatutnya harus ditiadakan. Karena pada bulan Mei 2011 WHO menetapkan bahwa gadget memiliki radiasi dan bisa berdampak kanker bagi AUD karena system imun yang rentan dan otak yang sedang berkembang (Fitriyani, n.d.).

Oleh karena itu kegiatan fisik tidak bisa diremehkan, karena pengabaian pada aktivitas fisik secara terus menerus, maka akan berimbas pada kematangan jasmani/raganya dan juga akan menimbulkan obesitas, penyakit,dll. Selain itu, sebuah riset menemukan bahwa integrasi sensorimotor pada anak adalah hal yang fundamental bagi kesiapan sekolah, maka apabila ini tercerabut pada anak maka akan timbul masalah bagi mereka. Di sebuah sekolah di Seattle, Washington, siswa kelas tiga mempelajari konsep seni dan bahasa dengan aktivitas tarian yang memasukan regular spinning (berputar biasa), merangkak, berguling, bergoyang, jatuh terguling, menunjukkan dan mencocokan. Walaupun skor membaca di seluruh distrik itu menunjukan rata-rata penurunan setiap tahun $2 \%$, siswa yang terlibat dalam aktivitas menari menunjukan kenaikan 13\% dalam 6 bulan (Jensen, 2011).

Sehingga secara singkat kegiatan fisik benar-benar mempengaruhi pikiran, suasana hati, dan memori, dan juga kesehatan secara keseluruhan, terlebih mengurangi stress. Dan, latihan fisik juga merupakan salah satu cara terbaik untuk merangsang otak dan mendorong pemelajaran/learning (Jensen, 2011). 
Dengan demikian sangat disayangkan jika anak-anak yang jarang bergerak dan tidak dapat menyalurkan kebutuhan bergeraknya baik di rumah atau pun di sekolah dikarenakan kegiatan belajar yang hanya dilakukan untuk mengejar nilai akademik, terutama usia TK dan Pra-TK karena ingin cepat pandai menulis, membaca dan berhitung (calistung). Hal ini sebaiknya dihindari, karena jika dilakukan terus-menerus dan membuat anak tidak nyaman sehingga anak-anak tersebut akan terkena penyakit mental hectic ( kekacauan mental). Penyakit itu akan merasuki anak tersebut di saat kelas 2 atau 3 Sekolah Dasar (SD) (Balita diajarkan calistung saat SD potensi terkena mental hectic, 2008)

Sehingga tidak mencengangkan banyak aksi pelajar-pelajar saat ini yang menyimpang dari hal yang sewajarnya, seperti tawuran, dll. Dan hal ini tidak lain karena kebutuhan dan kecerdasan bodi kinestetik mereka tidak diwadahi sejak usia dini, karena menganggap kecerdasan matematika ataupun bahasa lebih harus diutamakan daripada kecerdasan bodi kinestetik, dengan demikian penulis berpikir sangatlah tepat jika anak-anak di sekolah diberikan suatu kegiatan yang mengasah imajinasi/daya pikir, kreatifitas dan juga gerak yang tepat sebagai wadah mereka untuk meningkatkan kemampuan gerak dan kecerdasan bodi kinestetik mereka, seperti tari kreatif. Karena tari kreatif merupakan gerakan yang mengekspresikan jiwa tanpa harus dibatasi oleh kemampuan gerakan dan imajinasi anak-anak, sehingga mereka bebas berekspresi, bergerak dan berimajinasi.

\section{TINJAUAN PUSTAKA}

\section{1. kecerdasan Bodi Kinestetik Anak Usia 5-6 Tahun}

Kecerdasan adalah kemampuan bawaan yang mampu mewujudkan berbagai kemungkinan, kemampuan ini dapat berkembang atau menurun bergantung kepada motivasi dan keadaan, pengalaman dan pendidikan yang relevan bagi diri seseorang(Gregory, 2000) . Kecerdasan merupakan kapasitas kemampuan mental seseorang untuk memproses informasi, memecahkan permasalahan yang dihadapi secara cepat dan tepat, menunjukkan perilaku yang tepat dalam menanggapi sesuatu yang baru, sehingga membuahkan hasil yang diinginkan. Kecerdasan merupakan potensi yang dapat dikembangkan dan merupakan modal dasar yang dimiliki manusia dalam proses belajar untuk dapat berpikir, beradaptasi, memecahkan masalah dan menciptakan sesuatu. Kecerdasan tidaklah tunggal melainkan ada beberapa yang juga dikenal dengan kecerdasan majemuk atau kecerdasan jamak yang dapat pula disebut multiple intelligence. Teori kecerdasan jamak telah dikembangkan oleh Gadner pada tahun 1983. Karena pada dasarnya semua manusia memiliki tidak hanya satu kecerdasan melainkan beberapa kecerdasan. kemampuan. Filosofi Gadner tentang kecerdasan jamak (Multiple Intelegence) menyatakan bahwa 
orang "pintar" dengan banyak cara (Gadner, 1993) . Hal tersebut yang menjadi alasan bahwa kecerdasan jamak dapat memandang anak sebagai individu yang unik. Salah satunya kecerdasan bodi kinestetik merupakan kemampuan menggunakan badan untuk menyatakan emosi (seperti dalam dansa/tari), untuk melakukan permainan (seperti dalam olahraga), atau menciptakan produk baru (seperti dalam mewujudkan penemuan) merupakan bukti dari sifat kognitif dari penggunaan badan.

Seseorang yang cerdas bodi kinestetik memiliki keahlian menggunakan seluruh tubuh untuk mengekspresikan ide-ide dan perasaan (seperti sebagai aktor, pantomim, atlet, atau penari) serta ketrampilan menggunakan tangan untuk menciptakan atau mengubah sesuatu (misalnya, sebagai pengrajin, pematung, mekanik, atau ahli bedah). kecerdasan ini termasuk keterampilan khusus fisik seperti koordinasi, keseimbangan, ketangkasan, kekuatan, kelenturan, dan kecepatan, serta proprioseptif (rasa tubuh), taktil (sentuhan), dan kapasitas haptik (pengaplikasian sensasi sentuhan ke dalam interaksi manusia dengan komputer/ perangkat dengan menggunakan teknologi) (Amstrong, 2009: 7).

Pendapat lain mengunngkapkan bahwa kecerdasan bodi kinestetik merupakan kecerdasan vital bagi bayi atau anak-anak yang sedang tumbuh, dan menyangkut kemampuan tubuh untuk berhubungan, baik dengan diri sendiri maupun dengan dunia sekitarnya, dengan cara yang anggun dan seimbang. Kecerdasan ini menyangkut kemampuan untuk merespon berbagai kecepatan, dari yang sangat lambat sampai ke yang sangat cepat, kemampuan untuk mewaspadai posisi tubuh dalam ruang berkaitan dengan objek-objek lain dalam ruang tersebut secara konstan, kemampuan untuk menentukan jarak fisik dengan objek terbang semacam bola, dan juga menilai kondisi kekuatan otot, fleksibilitas fisik, dan stamina jantung (Buzan, 2005) .

Oleh karena itu aplikasi kecerdasan jamak baik itu kecerdasan bodi kinestetik ataupun yang lainnya dalam pendidikan sepatutnya diaplikasikan dengan baik bukan hanya sebatas teori, dan pendidik diharapkan lebih arif dalam memberikan kegiatan dan mampu menghargai serta memfasilitasi perkembangan anak. Mengakui dan menerima perbedaan pada tiap individu juga merupakan sarana pengembangan kecerdasan anak.

\section{Tari Kreatif}

Sejak dalam kandungan seorang bayi telah melakukan tarian yaitu "tarian kehidupan", yang telah dimulai kurang lebih pada awal minggu kedua belas masa kehamilan, tak lama sebelum ibu merasakan gerak 
pertama dalam rahimnya. Setiap gerakan menciptakan sebuah ingatan kasar mengenai gerakan itu dalam otak. Setelah lahir, gerakan-gerakan dasar ini diulang secara bebas ratusan ribu kali dalam rangka meningkatkan ingatannya, membuat ingatan ini akurat dan memiliki tujuan, yaitu koordinasi otot yang maksimal. Oleh karena itu, sejak bayi seseorang telah terlahir sebagai seorang penari, dan bawaan serta bakat alam ini perlu didorong di sepanjang masa kanak-kanak dan kehidupannya(Buzan, 2005 : 286 ). Dengan demikian pada hakikatnya setiap anak telah memiliki gerakan tari sendiri dalam kehidupannya yang bebas dan tidak kaku. Kebebasan bergerak itu merupakan tari kreatif, sebab menurutnya gerakan bagi anak usia dini merupakan kemampuan awal untuk mengekspresikan perasaan tentang dirinya serta dunia mereka kepada orang lain. Dan ekspresi kreatif pada anak yaitu ketika mereka mengunakan tubuh mereka secara bebas (Fraser, 1991).

Tari kreatif merupakan kombinasi dari penguasaan gerakan dengan ekspresi yang artistik. Dan ini adalah sebuah kombinasi, bukan pemisahan dari keduanya, yang membuat tari kreatif begitu kuat (Gilbert, 1992) .

Dengan demikian tari kreatif sepertinya tari yang cocok bagi anak usia dini karena tidak membatasi ide dan kreativitas anak serta tidak direct teaching, karena gerakan berasal dari pengalaman anak itu sendiri.

\section{METODE}

Metode penelitian yang digunakan adalah metode action research atau penelitian tindakan yang dilakukan di TK/RA Daaruttuqo dengan melibatkan 10 anak pada kelompok B. Penelitian tindakan kelas merupakan suatu pendekatan untuk meningkatkan pendidikan dengan melakukan perubahan atau perbaikan terhadap hasil pendidikan atau pembelajaran(Arikunto, Suharsimi, 2008). Penelitian tindakan dilakukan secara kolaboratif partisipatif dalam rangka memecahkan atau memperbaiki suatu masalah yang terjadi pada komunitas atau kelompok tertentu.

\section{HASIL DAN PEMBAHASAN}

\section{Deskripsi Hasil Temuan}

Penelitian dilakukan dua siklus dengan masing-masing siklusnya sebelas pertemuan. Pertemuan dilakukan seminggu 5 kali. Sebelum melakukan siklus 1, peneliti melakukan persiapan pra-penelitian yaitu mencari dan mengumpulkan data-data anak yang akan diteliti melalui observasi serta diskusi dengan guru kelas.

Berdasarkan hasil observasi kecerdasan bodi kinestetik anak pada pra siklus menunjukkan bahwa sebagian anak belum mampu mencapai indikator kecerdasan bodi kinestetik, yaitu aspek ekspresi, koordinasi, keseimbangan, keluwesan, ketangkasan dan kecepatan. Saat peneliti dan 
kolaborator melakukan observasi, terlihat bahwa sebagian besar anakanak belum mampu menggerakkan tubuh secara seimbang, belum dapat bergerak secara tangkas, belum mampu berkreasi dengan gerakan sendiri. Pada tiap akhir siklus peneliti melakukan observasi. Observasi hasil tindakan yang dilakukan selama pelaksanaan sangat diperlukan dalam melakukan analisis data secara kuantitatif dan kualitatif. Berdasarkan hasil observasi, diperoleh prosentase skor pada prapenelitian tertinggi sebesar 41\% dan terendah 35\%. Hasil tersebut masih dibawah kriteria keberhasilan yang diharapkan yaitu 80-89\%. Hal tersebut juga menunjukan masih rendahnya kecerdasan bodi kinestetik anak.

Selain pada prapenelitian, saat akhir siklus 1 dan siklus 2 juga dilakukan observasi dengan prosentase peningkatan sebagai berikut :

Table 1. Prosentase Perolehan Skor Observasi Kecerdasan bodi kinestetik

\begin{tabular}{lccc}
\hline Nama & $\begin{array}{c}\text { pra-tindakan } \\
\mathbf{( \% )}\end{array}$ & $\begin{array}{c}\text { siklus I } \\
\mathbf{( \% )}\end{array}$ & $\begin{array}{c}\text { siklus II } \\
\mathbf{( \% )}\end{array}$ \\
\hline ZR & 35 & 59 & 75 \\
\hline AA & 40 & 59 & 88 \\
\hline EA & 38 & 60 & 88 \\
\hline MF & 39 & 48 & 75 \\
\hline KJA & 40 & 59 & 89 \\
\hline MI & 36 & 59 & 76 \\
\hline AS & 36 & 50 & 75 \\
\hline SR & 36 & 56 & 81 \\
\hline RSI & 39 & 59 & 78 \\
\hline FR & 36 & 58 & 84 \\
\hline
\end{tabular}




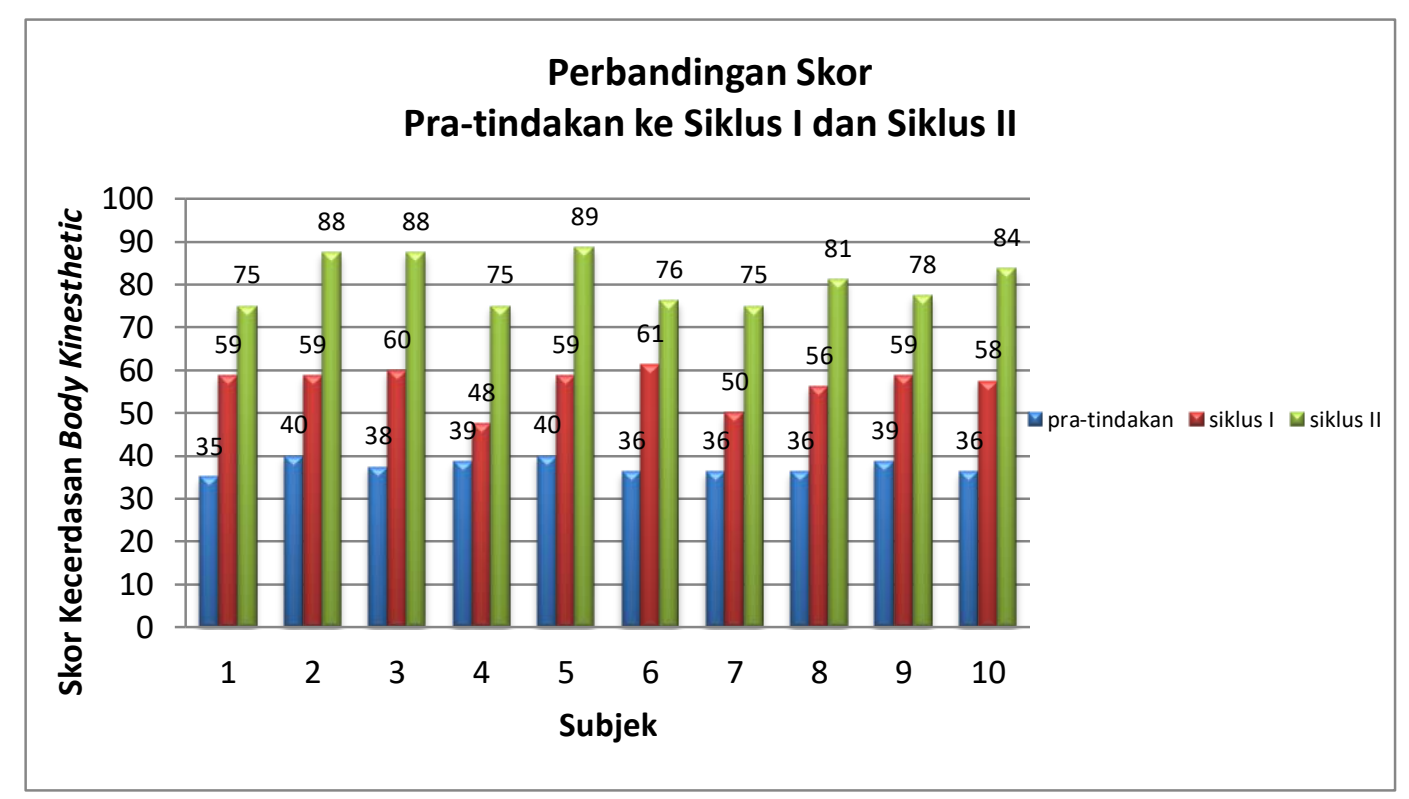

Gambar 1. Perbandingan Skor Pra-tindakan ke Siklus 1 dan Siklus 2

Berdasarkan hasil analisis kuantitatif, pada prapenelitian terlihat AA dan KJA mendapat prosentase tertinggi dan prosentase terendah diperoleh ZR. Hasil perolehan di siklus 1 ada EA, dan siklus 2 terlihat kembali bahwa KJA mendapat skor prosentase tertinggi. Perolehan prosentase skor terendah pada pra penelitian ZR dan siklus1 diperoleh MF, sedangkan pada siklus 2 diperoleh AS, MF dan ZR.

\section{Pembahasan}

Observasi hasil tindakan yang dilakukan selama pelaksanaan sangat diperlukan dalam melakukan analisis data secara kuantitatif dan kualitatif. Observasi dilakukan dengan menggunakan: instrumen observasi, pedoman observasi dilakukan dengan indikator, catatan lapangan, dokumentasi dan wawancara.

Secara kuantitatif, berdasarkan pengamatan yang dilakukan pada siklus 1 dan siklus 2, diperoleh persentasi kenaikan kecerdasan bodi kinestetik yang meliputi aspek-aspek yaitu ekspresi, koordinasi, keseimbangan, keluwesan, ketangkasan serta kecepatan. Persentasentasi kenaikan keseluruhan skor observasi sebagai berikut : ZR sebesar $40 \%$, AA sebesar 48\%, EA sebesar 50\%, MF sebesar 34\%, KJA sebesar $49 \%$, MI sebesar $42 \%$, AS sebesar 39\%, SR sebesar $45 \%$, RSI sebesar $41 \%$, dan FR sebesar 55\%. Berdasarkan perbandingan prosentase seluruh tindakan kecerdasan bodi kinestetik anak pra penelitian, siklus I dan siklus II dapat dilihat terjadinya peningkatan kecerdasan bodi kinestetik anak. Di awal pra penelitian ke siklus I terdapat peneingkatan sedikit 
demi sedikit, hal tersebut bisa terjadi dikarenakan anak-anak belum terbiasa denngan kegiatan tari kreatif, sedangkan anak lebih sering atau terbiasa menunggu tanpa tujuan. Namun pada siklus 2, anak-anak mulai terbiasa. Hal ini dapat dimungkinkan oleh beberapa faktor, diantaranya, anak sudah mulai terbiasa dengan kegiatan tari kreatif. Kondisi tersebut sesuai dengan teori belajar Piaget bahwa pada proses belajar anak akan memerlukan adaptasi, adaptasi memerlukan keseimbangan antara dua proses yang saling menunjang yaitu asimilasi dan akomodasi. Asimilasi dan akomodasi terjadi sama-sama saling mengisi pada setiap individu yang menyesuaikan diri dengan lingkungannya. Antara asimilasi dan akomodasi harus ada keserasian atau disebut keseimbangan atau Ekuilibrium (Mutiah, 2010) . Pada anak kelompok B TK/RA Daaruttuqo, mereka juga melalui tahapan tersebut diatas. Mereka perlu beradaptasi terlebih dahulu sebelum mereka terbiasa dengan kegiatan tari kreatif sehingga skor prosentase di siklus II lebih baik atau lebih tinggi dari siklus I.

Selain adaptasi, faktor lainnya adalah ketertarikan dengan media dan aktivitas. Pada siklus 1, kegiatan hanya pada gerakan dasar yang disesuaikan dengan tema, sedangkan pada siklus kedua diberi tambahan media, seperti papan titian, buah-buahan plastik, serta kegiatan lebih variatif yaitu bermain secara kooperatif. Hal ini juga merupakan perbaikan pemberian tindakan berdasarkan refleksi di siklus 1 yaitu anak masih bingung atau belum terbiasa dengan kegiatan tari kreatif. Kemp dan Dayton mengungkapkan mengenai manfaat media dalam pembelajaran diantaranya proses pembelajaran menjadi lebih menarik, kualitas belajar siswa dapat ditingkatkan, sikap positif siswa terhadap bahan pelajaran maupun terhadap proses belajar dapat ditingkatkan.

Berdasarkan hasil analisis kuantitatif juga terlihat bahwa KJA mendapat skor prosentase tertinggi di siklus 2, dan di siklus 1 ada EA sedangkan pada pra penelitian AA mendapatkan skor prosentase tertinggi. Perolehan prosentase skor terendah pada pra penelitian ada ZR dan siklus 1 diperoleh MF, sedangkan pada siklus 2 diperoleh SA, MF dan ZR. Perolehan prosentase pada tiap siklusnya berbeda. Hal ini dapat dipengaruhi oleh faktor intern dan ekstern diantaranya yaitu faktor bawaan atau keturunan, faktor minat dan pembawaan yang khas, faktor pembentukan atau Lingkungan, faktor kematangan, faktor Kebebasan.

Pada perolehan prosentase skor tertinggi oleh KJA dimungkinkan dipengaruhi oleh faktor-faktor pendukung tersebut di atas. Berdasarkan faktor keturunan, seperti belum dapat dinyatakan sebagai pendukung utama, namun jika kita melihat latar belakang keluarga, KJA berasal dari keluarga yang berpendidikan, ayahnya berprofesi sebagai karyawan 
swasta lulusan S1, ibunya lulusan SMA (berdasarkan biodata murid). Jika dilihat dari faktor minat, KJA memang memiliki minat atau ketertarikan yang besar untuk bergerak meskipun pada observasi prapenelitian koordinasi gerakannya tidak stabil atau setiap mengerjakan sesuatu dengan terburu-buru (berdasarkan observasi selama penelitian). KJA terlihat senang dan antusias saat kegiatan tari kreatif maupun saat guru menerangkan sedangkan berdasarkan faktor pembentukan atau lingkungan juga berkaitan dengan faktor kebebasan, Orang tua KJA memang mendukung dan menfasilitasi minat atau kesukaan dengan menyediakan sarana atau media edukatif serta sering mengajak KJA berjalan-jalan ke tempat-tempat wisata yang edukatif (berdasarkan hasil wawancara dengan orang tua.

Pada perolehan prosentase skor terendah oleh MF di siklus 1 dan 2, dimungkinkan dipengaruhi oleh faktor-faktor pendukung tersebut di atas seperti halnya KJA namun berbeda pada kondisinya. Berdasarkan faktor keturunan, seperti belum dapat dinyatakan sebagai pendukung utama namun jika kita melihat latar belakang keluarga, MF berasal dari keluarga yang cukup berpendidikan, ayahnya berprofesi sebagai karyawan swasta dan ibunya sebagai ibu rumah tangga lulusan SMA (berdasarkan biodata murid) Jika dilihat dari faktor minat, MF memang kurang memiliki minat atau ketertarikan yang besar dengan aktifitas diberikan karena kadang sering melamun atau tidak fokus (berdasarkan observasi selama penelitian). MF mau melakukan terlihat lebih antusias mengikutinya jika dilakukan secara kooperatif. Jika dilihat dari faktor pembentukan atau lingkungan juga berkaitan dengan faktor kebebasan, Orang tua MF kurang memberikan atau kurang memfasilitasi MF dengan sarana pembelajaran edukatif. Di rumah MF lebih sering bermain play station dan menonton televisi (berdasarkan wawancara dengan guru). Jika dilihat dari faktor kematangan, usia MF memang lebih muda dibanding usia rata-rata dikelasnya. Perbedaan perolehan prosentase skor yang bervariatif dapat saja dikarenakan gaya belajar anak yang berbeda-beda dan selalu dinamis. Samples dalam Mayke berpendapat bahwa pemahaman mendalam terhadap kecerdasan individual masing-masing anak dan gaya belajar mereka akan membantu para pendidik dalam menghadapi anak terutama dalam mengajari anak-anak dengan cara yang paling sesuai dengannya atau dengan cara yang paling mudah untuk mereka dapat menguasai suatu pelajaran atau pekerjaan, menangkap informasi atau konsep atau berbagai keterampilan secara lebih cepat. Kegiatan tari kreatif yang diberikan sebaiknya diimbangi dengan kegiatan pendamping berimbang dengan gaya belajar yang dimiliki anak. 
Anak yang sudah memiliki atau lebih dominan kecerdasan bodi kinestetiknya akan lebih mudah meningkat dibanding anak yang lebih dominan kecerdasan lainnya (linguistik, matematika logika, dan sebagainya) karena setiap orang memiliki beberapa kecerdasan dalam tingkat yang berbeda-beda. Hal tersebut seperti yang diungkapkan Gadner dan Amstrong tentang konsep dasar kecerdasan jamak yaitu: 1. Setiap orang memiliki semua (delapan) kecerdasan, 2. Manusia mempunyai kemampuan meningkatkan dan memperkuat kecerdasannya, 3. kecerdasan saling berkaitan dalam satu rangkain. Hal tersebut diatas dapat mempengaruhi pencapain prosentase skor pada tiap anaknya.

Hasil data kualitatif membuktikan bahwa rangkaian pemberian tindakan berupa tari kreatif mampu meningkatkan kecerdasan bodi kinestetik anak karena memberikan kesempatan pada anak untuk beraktivitas dan bergerak dengan tujuan dan memberi kesempatan pada anak untuk berkreasi. Berkreasi adalah bagian dari kreatifitas, Fraser mengungkapkan bahwa kreatifitas memiliki keterkaitan dengan intelegensi/kecerdasan, beberapa penelitian melihat realita bahwa ini memiliki sedikit keterkaitan dengan "kekuatan otak". Dengan demikian kreatifitas adalah bagian dari kecerdasan dan memiliki keterkaitan dengan pembelajaran berbasis otak (brain based learning) (Jensen, 2011: 52 ) .

Dan kreatifitas adalah konsep yang dapat ditinjau dari beberapa aspek yang memiliki keterkaitan dengan penekanan-penekanan yang berbedabeda, seperti dalam Jamaris bahwa kreatifitas dilihat dari berbagai sudut pandang, yaitu: sudut kepribadian, dan penghasilan produk :1).Kreatifitas menurut santrock dalam Jamaris adalah kemampuan untuk memikirkan sesuatu dengan cara-cara yang baru dan tidak biasa dan melahirkan suatu solusi yang unik terhadap masalah-masalah. 2).Sedangkan menurut para psikoanalisis seperti Freud, Jung, E. Krist, L. Kubie dalam Jamaris keratifitas merupakan kemampuan seseorang untuk mengendalikan tekanan regresi yang ada dalam dirinya. 3).Para humanistik seperti Maslow dan Carl Roger mendefinisikan bahwa kretifitas sebagai salah satu aspek kepribadian yang berkaitan dengan aktualisasi diri atau proses dari aktualisasi diri. Karena menurut mereka setiap individu terlahir kreatif. 4).Sedangkan menurut teori Gestalt dan teori Psikometrik kreatifitas sebagai kemampuan mental kemudian berproses yang mendasari pikiran-pikiran kreatif.

Sehingga dalam hal ini kreatifitas merupakan bagian penting dalam kehidupan seseorang selain penanaman rasa percaya diri, kemampuan menganalisis regresi dalam dirinya juga menghasilkan produk dari ide dan karyanya. Oleh karena itu pengembangan kreatifitas anak usia dini 
sangat penting. Salah satu pengembangan kreatifitas bagi anak usia dini adalah melalui seni, khususnya gerak tari. Berdasarkan uraian di atas, maka dapat dikatakan bahwa melalui kegiatan tari kreatif mampu meningkatkan kecerdasan bodi kinestetik anak.

\section{SIMPULAN}

Berdasarkan hasil analisis data dan pembahasan, dapat diambil kesimpulan bahwa proses kegiatan tari kreatif telah dilaksanakan dengan baik oleh peneliti dan kolaborator. Kegiatan tari kreatif yang dirancang dengan variatif dan menarik mampu menciptakan suasana belajar yang aktif dan menyenangkan serta menghadirkan lingkungan belajar yang lebih menantang dan variatif sehingga terjadi perubahan pada aspek-aspek perkembangan anak yang diikuti dengan peningkatan kecerdasan bodi kinestetik anak.

\section{REFERENSI}

Arikunto, Suharsimi. Dasar-dasar Evaluasi Pendidikan Jakarta:Bumi Aksara : 2006

Arikunto, Suharsimi et.al. Penelitian Tindakan Kelas, PT. Bumi Aksara: Jakarta; 2008.

Buzan, Tony. Brain Child; cara pintar membuat anak jadi pintar, (Gramedia Pustaka Utama : Jakarta), Cet. II : 2005

Departemen Pendidikan Nasional RI, Undang-undang Republik Indonesia Nomor 20 Tabun 2003 tentang Sistem Pendidikan Nasional. Jakarta:2003.

Fraser, Diane Lynch, Playdancing(Pennington: Princeton book Company, 1991

Gilbert, Anne Green. Creative dance, Virginia; National Dance association, 1992

Howard, Gadner.Frames Of Mind The Theory of Multiple Intelligences, tenthanniversary edition, New York: Basic Books A Member of The Perseus Books Group.1993

Jensen, Eric. Pemelajaran berbasis-otak (Indeks : Jakarta ;2011. Jasminne, Julia. Profesional's Guide Teaching With Multiple Intelligences (Teacher Created Material Inc,2011.

Masardi, Yudistira dan Sisca Y.,Pendidikan Karakter Dengan Metode Sentra, Penerbit: Media Pustaka Sentra, Bekasi :2012

Mutiah, Diana. Psikologi Bermain Anak Usia Dini, Kencana, Cet. I. Jakarta : 2010 
Sugiyono, Metodologi Penelitian Kualitatif Edisi Revisi. Bandung : CV. Alfabeta, 2005.

Suharsimi Arikunto. Prosedur Penelitian Suatu Pendekatan Praktik. Jakarta: Rineka Cipta, 2006.

Teacher Created Resources, The Best of Multiple Intelegence Activities. Teacher Created Resources inc, 1998.

Thomas Armstrong.Multiple Intelligences in the Classroom $3^{\text {rd }}$ Edition.Virginia USA:ASCD Publication, 2009.

Undang-undang Republik Indonesia Nomor 20 Tabun 2003 tentang Sistem Pendidikan Nasional (Jakarta: Kementrian Pendidikan Nasional Republik Indonesia, 2003) 